\title{
Model Triple Helix dalam Meningkatkan Pendapatan Asli Daerah Kota Baubau
}

\author{
Asmiddin ${ }^{1 *}$, Syahril Ramadhan ${ }^{1}$, Kalsum ${ }^{1}$ \\ ${ }^{1}$ Fakultas IImu Sosial dan IImu Politik Universitas Dayanu Ikhsanuddin, Indonesia \\ "Korespondensi: asmiddin@unidayan.ac.id
}

\begin{tabular}{|c|c|}
\hline & \multirow{6}{*}{ 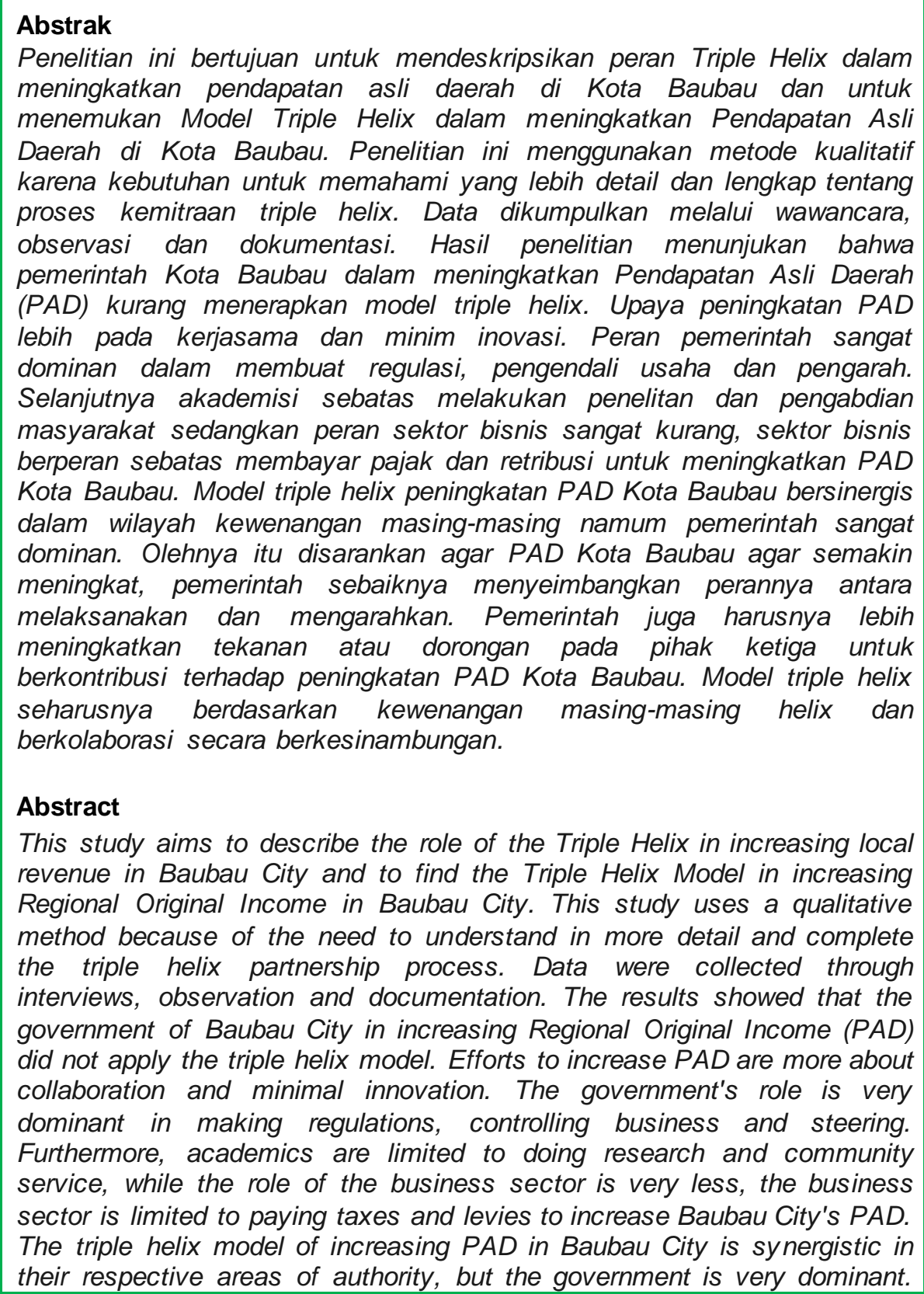 } \\
\hline & \\
\hline & \\
\hline & \\
\hline & \\
\hline & \\
\hline
\end{tabular}


Therefore, it is recommended that the PAD of Baubau City is increasing, the government should balance its role between implementing and directing. The government should also increase the pressure or encouragement on third parties to contribute to the increase in Baubau City's PAD. The triple helix model should be based on the authority of each helix and collaborate on an ongoing basis

\section{Pendahuluan}

Fakta empiris menunjukkan bahwa Pendapatan Asli Daerah Kota Baubau menunjukan perkembangan yang belum optimal dan masih berfluktuasi. Hal ini tercermin dalam realisasi pajak daerah Kota Baubau dalam kurun waktu 3 tahun dimulai pada tahun 2016 sampai dengan tahun 2018 yang dibebankan kepada pajak daerah belum dapat tercapai sesuai target yang ditetapkan. Target pendapatan asli daerah Kota Baubau sebesar Rp. 34.440.704.101 dan yang terealisasi Rp. 44.105.333.214, di tahun 2017 target PAD Rp. 86.960.301.451 dan realisasi sangat signifikan yaitu $R p .106 .249 .590 .521,36$ dan di tahun 2018 target PAD menurun dari tahun sebelumnya yaitu Rp. 72.581.399.292 dan yang terealisasi jauh dari target yaitu Rp. 67.220.777.535, (Sumber data: pelaporan evaluasi pendapatan asli daerah Kota Baubau, Dinas Pendapatan Kota Baubau 2016,2017 dan 2018). Selain itu Kota Baubau telah merencanakan Rancangan Anggaran Pendapatan Belanja Daerah (RAPBD) tahun 2018 mencapai Rp 847.5 miliar, (Baubau Post, 2018). Sedangkan untuk RAPBD 2019 direncanakan Rp. 957.4 miliar.

Kondisi Pendapatan Asli Daerah (PAD) Kota Baubau menunjukan fenomena sumber pendapatan atau inovasi dalam meningkatan PAD Kota Baubau yang fluktuatif sehingga perlu ditelusuri lebih mendalam, karena penurunan tingkat PAD sangat signifikan antara tahun realisasi tahun 2017 dengan target di tahun 2018. Inovasi pemerintah daerah dan lembaga terkait dalam meningkatkan PAD belum mampu meningkatkan PAD secara berkelanjutan, namun yang terjadi fluktuatif dan bahkan turun secara signifikan.

Penggenjotan Pendapatan Asli Daerah di lakukan oleh pemerintah sebagai aktor utama dalam menarik sumber pajak yang sebetulnya dapat melibatkan pihak lain seperti pihak industri (swasta) dan pendidikan tinggi. Pemerintah dapat bermitra dengan kedua aktor tersebut dalam mendesain atau menggali potensi atau sumber pajak. Pelibatan ketiga aktor ini dalam teori administrasi publik dikenal dengan istilah triple helix. Triple helix merupakan bentuk "interaksi antara universitas, industri, dan pemerintah adalah kunci untuk inovasi dan pertu mbu han dalam ekonomi berbasis pengetahuan" (Etzkowitz, 2008).

Model triple helix penting bagi daerah dalam peningkatan pendapatan asli daerah. Hal ini berdasarkan asumsi bahwa kolaborasi dari tiga aktor Triple Helix dianggap mampu meningkatkan kreativitas, ide dan skill (Etzkowitz, 2008), termasuk dalam rangka peningkatan pendapatan asli daerah. Konsep Triple Helix mewakili keterkaitan hubungan antara tiga domain institusional (universitas industri - pemerintah) dengan tujuan meningkatkan daya saing suatu daerah melalui pengembangan tindakan yang saling terkait dalam skenario multi-level. Konsep Triple Helix berfungsi sebagai batu loncatan untuk mengembangkan dan 
melakukan penelitian empiris dengan tujuan untuk memberikan jawaban atas interaksi (antar aktor) yang terjadi dalam berbagai disiplin ilmu (sosial, ekonomi, politik, dan budaya) (Fadli \& Nurlukman, 2018:527).

Model triple helix ini telah diuji dalam berbagai penelitian di antaranya Etzkowitz et al. (2000) menguji konsep "triple helix" untuk menggambarkan hubungan yang sinergis antara tiga pihak terkait (akademisi, industri, dan pemerintah). Sementara konsep ini mereka dasarkan layaknya seprti konsep biologis model DNA dimana, konsep ini menekankan interaksi antara banyak pihak atau pemain kunci yang terlibat dalam menghasilkan produk berbasis sains, ekspansi industri, dan layanan sebagai landasan sistem inovasi.

Terkait Model triple helix dalam penelitian terdahulu Izzati \& Wilopo (2018) menemukan bahwa peran pemerintah dalam mendorong pertumbuhan industri kreatif di Kota Malang terutama sebagai fasilitator. Sementara pemerintah bertindak sebagai regulator untuk memastikan peningkatan daya saing terhadap Masyarakat Ekonomi ASEAN (MEA) di Kota Malang, peran pemerintah terutama sebagai fasilitator. Selain itu, para sarjana berkontribusi pada pertumbuhan sektor kreatif di Kota Malang melalui komitmen dan studi mereka. Sedangkan peran pelaku usaha dalam mendorong pertumbuhan industri kreatif di Kota Malang adalah berperan sebagai investor, terdapat juga kesenjangan dalam peran jaringan implementasi Triple Helix dalam mendorong pertumbuhan industri kreatif di Kota Malang, dimana peran akademisi tidak dikenali dalam perhitungan nilai jaringan. Kondisi optimal untuk fungsi Triple Helix adalah agar ketiganya bekerja secara ideal; Dengan kata lain, jaringan pertumbuhan industri kreatif Kota Malang tidak bisa lagi dijuluki Triple Helix, melainkan hanya Double Helix (Izzati, 2018:66)

Temuan peneliti terdahulu (Daulay, 2018) tentang perkembangan ekonomi kreatif di Kota Medan dan pola strategi yang digunakan untuk pengembangan ekonomi kreatif melalui pendekatan analisis SWOT dengan model Triple Helix. Hasil temuan menunjukan bahwa pola interaksi antara ketiga aktor (pelaku bisnis, pemerintah dan akademisi) harus berkolaborasi secara simbiosis mutualisme dalam merancang dan mengembangkan ekonomi kreatif dengan strategi yang digunakan untuk mengembangkan ekonomi kreatif.

Temuan yang sama pula di sampaikan (Wasitowati, 2015:120) tentang Hubungan Triple Helix, Inovasi, Keunggulan Bersaing dan Kinerja. Hasil penelitian menunjukkan dari ketiga aktor Triple Helix (intellectual, government, business) berpengaruh signifikan terhadap kemampuan inovasi dan keunggulan bersaing. Artinya bahwa model triple helix penting bagi daerah dalam peningkatan pendapatan asli daerah. Hal ini berdasarkan asumsi bahwa kolaborasi dari tiga aktor Triple Helix dianggap mampu meningkatkan kreativitas, ide dan skill (Etzkowitz, 2008), termasuk dalam rangka peningkatan pendapatan asli daerah.

Berbagai temuan dan teori triple helix yang diketengahkan di atas, menggambarkan bahwa model triple helix dapat dijadikan rujukan bagi pemerintah daerah khususnya Kota Baubau dalam rangka meningkatkan Pendapatan Asli Daerah yang mana dua tahun terakhir mulai menunjukan angka penurunan PAD Kota Baubau. Menurut Izzati \& Wilopo (2018) triple helix penting karena sinergi dari ketiga sektor ini merupakan prinsip generatif dalam membangun ekonomi yang berbasis pengetahuan, yang memungkinkan tercapainya integrasi ekonomi 
yang lebih erat. Selain itu Triple Helix ini dianggap mampu meningkatkan kreativitas, ide dan skill (Etzkowitz, 2008).

\section{Landasan Teori}

Etzkowitz \& Leydersdorff mempromosikan gagasan Triple Helix sebagai alat untuk mengembangkan kebijakan inovatif. Gagasan yang menekankan pentingnya sinergi antara tiga aktor yaitu akademisi, bisnis, dan pemerintah (Etzkowitz et al., 2000). Konsep ini disebut sebagai konsep ABG di Indonesia (Academics, Business \& Governmenty) yang mana secara teoritis bertujuan untuk menciptakan ekonomi berkelanjutan berbasis sains melalui aktor-aktor Triple Helix (Akadmisi, Pemerintah, Pebisnis). Sinergi ini diyakini akan menghasilkan transmisi in formasi, terutama yang memiliki potensi ekonomi, atau modal pengetahuan.

Kolaborasi antara tiga aktor Triple Helix diyakini dapat meningkatkan kreativitas, ide, dan kemampuan (Etzkowitz, 2008). Keberhasilan kolaborasi ketiga aktor triple helix tersebut dimaksudkan untuk memberikan sinergi yang menguntungkan dan seimbang, sehingga masing-masing dapat menjalankan fungsinya secara ideal guna membangun sektor kreatif yang tangguh dan berkelanjutan(Wasitowati, 2015). Kementerian Perdagangan Republik Indonesia (2008) menyatakan (Wasitowati, 2015) bahwa hubungan yang erat, saling menguntungkan, dan simbiosis antara ketiga pemain tersebut merupakan landasan di mana sektor kreatif dapat berdiri kokoh dan berkembang secara berkelanjutan.

Mengingat konfigurasi ketiga aktor tersebut sebagai model keseimbangan yang melibatkan peran tiga pihak dalam rangka mewujudkan masyarakat berbasis pengetahuan; universitas dan institusi lain berpartisipasi aktif dalam kerjasama dengan industri dan pemerintah, termasuk pembentukan inisiatif bersama.(Rufaidah, 2015). Tentunya partnership ketiga stakeholder tersebut juga akan berdampak pada sektor ekonomi, sosial dan sektor-sektor lainnya. oleh karena itu partnership dalam triple helix penting dalam penunjang pembangunan baik ekonomi maupun sosial politik dan lain sebagainya.

Model triple helix mungkin tidak luput dari masalah sebagaimana dikatakan, (Iskandar, 2013) bahwa secara konseptual model triple helix belum dilakukan secara penuh karena iklim pemerintahan dan iklim industri masih perlu ditingkatkan lagi untuk menuju masyarakat berbasis pengetahuan. Untuk itu peran aktor triple helix diharapkan membangun sinergitas yang kokoh dan saling percaya agar berkontribusi positif bagi pembangunan, khususnya dalam peningkatan pendapatan asli daerah. 


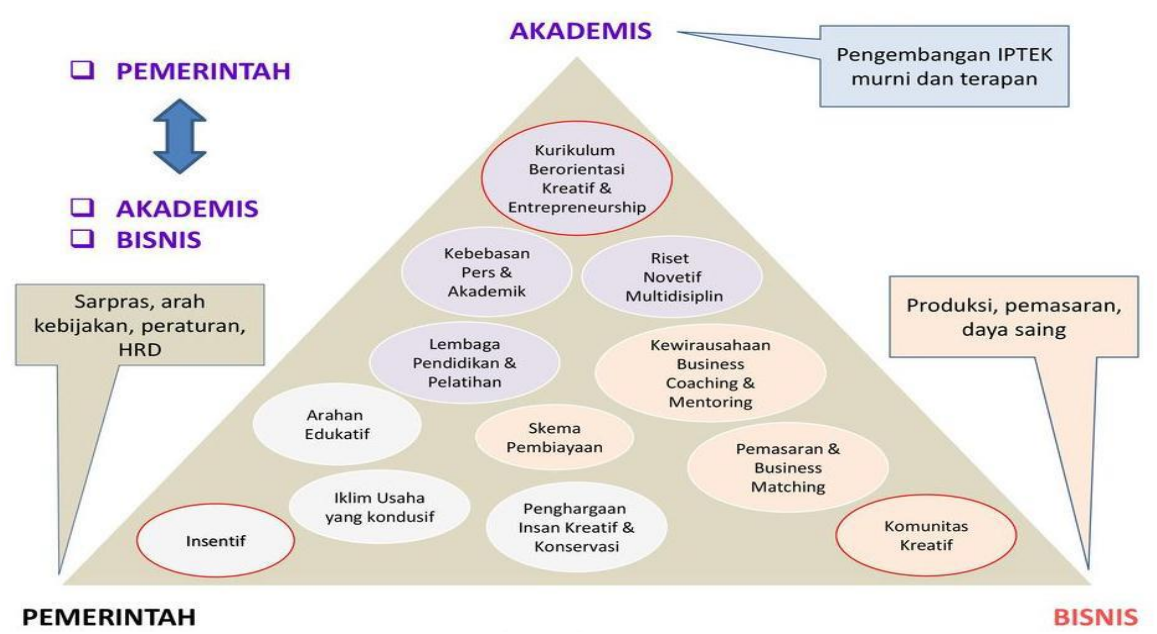

Gambar 1. Triple helix aktor penggerak pengembangan ekonomi kreatif (Model Trile Helix sumber Zul Asfi Arroyhan (Daulay, 2018).

\section{Metode Penelitian}

Penelitian ini menggunakan pendekatan kualitatif dimana yang menjadi instrumen utama adalah peneliti, (Moleong, 2002); (Sugiyono, 2017). Penelitian ini berlokasi di Kota Baubau dengan situs penelitian di Badan Pengelola Keuangan Aset Pendapatan Daerah Kota Baubau. Pemilihan situs penelitian ini berdasarkan pertimbangan bahwa Badan Pengelola Keuangan Aset Pendapatan Daerah yang memiliki kewenangan khsusus dalam pengelolaan keuangan daerah Kota Baubau. Mengingat kepentingan Faliditas hasil penelitian maka digunakan tiga sumber data yang dapat di jadikan sebagai sumber informasi dalam penelitian ini antaralain; Pertama, Informan kunci (key informan) yaitu Kepala Badan Pengelola Keuangan Aset Pendapatan Daerah, Kepala Bidang Pengelolaan aset daerah, dan Kepala Dinas Pendapatan Kota Baubau. Kedua, sumber peristiwa yaitu segala sesuatu yang berhubungan dengan peristiwa atau kejadian-kejadian dan situasi sosial yang berkaitan dengan masalah atau fokus penelitian yang diteliti yaitu peran aktor triple helix dalam meningkatkan PAD Kota Baubau. Ketiga, sumber dokumen yaitu sebagai sumber data lainnya yang bersifat melengkapi data utama yang relevan dengan masalah dan fokus penelitian, antara lain; catatan-catatan dan dokumen-dokumen resmi pemerintah berupa; a) laporan tahunan Badan Pengelola Keuangan Aset Pendapatan Daerah Kota Baubau, b) laporan Keungan Kota Baubau, dan c) laporan APBD Kota Baubau 2018.

\section{Hasil}

Model Triple helix dalam peningkatan Pendapatan Asli Daerah Kota Baubau diperlukan agar dapat meningkatkan pertumbuhan ekonomi di daerah. Semakin baik peran helix dalam mendorong pembangunan ekonomi semakin besar pula peluang terwujudnya pembangunan di daerah, sebaliknya jika triple helix yaitu pemerintah, akademisi dan sektor industri tidak membangun komitmen yang kuat dalam pembangunan ekonomi maka pencapaian tujuan pembangunan akan sulit dicapai, oleh karena itu peran triple helix sangat penting dan dibutuhkan dalam pembangunan di daerah, untuk melihat peran triple helix dalam peningkatan PAD dapat dideskripsikan pada peran masing-masing helix. 


\subsection{Peran pemerintah}

Menyangkut pendekatan aktor, pemerintah merupakan helix utama dalam menggerakan pertumbuhan ekonomi suatu daerah khususnya yang terkait dengan peningkatan PAD. Semakin baik peran triple helix semakin besar peluang peningkatan $P A D$, sebaliknya jika PAD suatu daerah mengalami stagnasi atau penurunan maka perlu dipertanyakan bagaimana peran triple helix.

Melalui peran tersebut dapatlah diketahui bahwa pemerintah telah berupaya meningkatakn PAD melalui pembuatan beberapa regulasi terkait pengembangan Ekonomi kreatif dan pelibatan perguruan tinggi dalam meningkatkan PAD Kota Baubau. Selain itu, pemerintah telah melakukan pengendalian iklim usaha di pasar Wameo agar masyarakat dapat memanfaatkan fasilitas dengan baik serta memberikan pembinaan masyarakat ekonomi kreatif di kelurahan Sulaa dalam mengembangkan kerajinan kain tenun. Namun pemerintah masih menjadi eksekutor utama dalam pengembangan ekonomi kreatif dibanding helix lainnya.

\subsection{Peran Akademisi}

Akademisi atau perguruan tinggi berperan dalam rangka peningkatan Pendapatan Asli Daerah. Akademisi atau perguruan tinggi memiliki tanggung jawab sebagaimana dalam Tri Dharma Perguruan Tinggi. Perguruan tinggi melalui penelitian dan pengabdian masyarakat diharapkan dapat memberikan kontribusi positif bagi kemajuan daerah khususnya terkait peningkatan ekonomi kreatif dan pemberdayaan masyarakat guna menunjang pembangunan di daerah. Untuk itu pemerintah menyadari peran perguruan tinggi, maka perlu dilibatkan dalam perumusan kebijakan pengembangan ekonomi kreatif dan berbagai kebijakan lainnya, sehingga dapatlah diketahui bahwa dalam rangka peningkatan PAD Kota Baubau perguruan tinggi telah berperan melalui kegiatan penelitian dan pengabdian masyarakat. Penelitian yang dilakukan pendidikan tinggi telah melahirkan dokumen rumusan kebijakan pengembangan ekonomi kreatif pada tahun 2018 dan seminar dan workshop pengembangan ekonomi kreatif yang dilaksanakan pada hari selasa, 27 Agustus 2019. Namun perguruan tinggi belum secara langsung mengawasi kegiatan sebagaimana dalam rekomendasi kajian akademik pengembangan ekonomi kreatif Kota Baubau.

\subsection{Peran sektor Bisnis}

Peningkatan PAD dibutuhkan keterlibatan berbagai pihak. Keterlibatan berbagai helix bukan sebatas memberikan kontribusi melalui pajak atau retribusi melainkan berkontribusi melalui keterlibatan langsung dalam menyusun stratgei untuk peningkatan PAD. Setiap helix diberi kesempatan yang sama dalam mengikuti proses perumusan kebijakan yang terkait langsung dengan hajat hidup orang banyak, dengan demikian dapatlah diketahui bahwa peran sektor bisnis dalam peningakatan pendapatan asli daerah Kota Baubau dilakukan melalui membayar pajak dan retribusi. Sektor bisnis bersifat pasif dalam peningkatan PAD dan tidak berperan serta dalam merumuskan berbagai kebijakan yang berkontribusi terhadap peningkatan pendapatan asli daerah Kota Baubau.

Secara umum model triple helix peningkatan PAD Kota Baubau belum berimbang. Peran pemerintah sangat dominan dalam membuat regulasi, pengendali usaha dan pengarah. Selanjutnya akademisi atau pendidikan tinggi sebatas melakukan penelitan dan pengabdian masyarakat sedangkan sektor 
bisnis sebagai peserta wajib pajak dan retribusi untuk meningkatkan PAD Kota Baubau.

\section{Pembahasan}

Sebagaimana diketahui hasil penelitian ini menunjukan bahwa model triple helix peningkatan PAD Kota Baubau belum berimbang. Peran pemerintah sangat dominan dalam membuat regulasi, pengendali usaha dan pengarah. Selanjutnya akademisi atau pendidikan tinggi sebatas melakukan penelitan dan pengabdian masyarakat sedangkan sektor bisnis sebagai peserta wajib pajak dan retribusi untuk meningkatkan PAD Kota Baubau.

Hasil penelitian di atas dapatlah didekripsikan bahwa model triple helix belu m menjadi perhatian utama pemerintah dalam meningkatkan PAD Kota Baubau. Pemerintah masih memberikan andil yang sangat besar dalam penyelenggaraan pemerintahan. Lembaga-lembaga lain yang sebetulnya dapat dioptimalkan perannya dalam menunjang pelaksanaan tugas pemerintahan tidak dilakukan sebagaimana mestinya.

Konteks administrsi publik, semangat pemerintah lebih mengutamakan melaksanakan ketimbang menggerakan pihak ketiga untuk berkontribusi terhadap peningkatan PAD. Sehingga nampak bahwa pihak lain terlibat hanya sebatas untuk memenuhi unsur tuntutan publik dan bukan karena menaruh harapan besar pada pihak akademisi dan bisnis untuk meningkatkan PAD. Hasil penelitian ini relevan dengan temuan penelitian Wilopo bahwa peran pemerintah adalah mendorong pertumbuhan industri kreatif melalui peran sebagai regulator dan juga fasilitator. Peran akademisi dalam mendorong pertumbuhan industri kreatif dengan pengabdian dan juga melakukan penelitian dan peran bisnis dalam mendorong pertumbuhan industri kreatif adalah menjadi investor.

Perbedaannya dengan penelitian ini adalah pada sektor bisnis, dalam peningkatan PAD Kota Baubau. Peran sektor bisnis adalah membayar retribusi dan pajak sedangkan di Kota Malang peran bisnis adalah sebagai investor dalam rangka mengembangkan ekonomi kreatif. Namun demikian pada prinsipnya kedua penelitian ini menemukan adanya peran triple helix dalam peningkatan ekonomi pemerintah daerah. Selain itu, hal menarik adalah peran perguruan tinggi, yang mana tidak selamanya perguruan tinggi memiliki peran yang sama dalam peningkatan pembangunan ekonomi. Sebagian akademisi atau perguruan tinggi kurang memperhatikan kegiatan penelitian dan pengabdian masyarakat. Hal ini sebagimana temuan penelitian Afzal et al. (2017) bahwa penerapan model Triple Helix di universitas negeri Malaysia dapat diterima. Universitas Nasional Malaysia (UKM) berkinerja buruk sementara Universitas Putra Malaysia (UPM) tampil lebih baik daripada yang lain.

Perbedaan peran perguruan tinggi sebagaimana penelitian di atas menjadi penting untuk diperhatikan, karena terkait pelaksanaan Tri Dharma perguruan tinggi. Perguruan tinggi seharusnya lebih meningkatkan kegiatan penelitian dan berkolaborasi dengan pemerintah. perguruan tinggi juga bukan hanya sebatas melakukan penelitian-penelitian yang kurang kontribusinya pada pemerintah dan masyarakat, melainkan harus lebih produktif sehingga terjalin kolaborasi simbiosis mutualisme (saling menguntungkan). 
Keberhasilan kolaborasi ketiga aktor triple helix tersebut dimaksudkan un tuk memberikan sinergi yang positif dan seimbang, sehingga masing-masing dapat bekerja secara efektif guna membangun sektor kreatif yang tangguh dan berkelanjutan (Wasitowati, 2015). Kementerian Perdagangan Republik Indonesia (2008) menyatakan (Wasitowati, 2015) bahwa hubungan yang erat, saling menguntungkan, dan simbiosis antara ketiga pemain tersebut merupakan landasan di mana sektor kreatif dapat berdiri kokoh dan berkembang secara berkelanjutan.

Hubungan sinergitas triple helix bukan hanya dalam program tertentu saja melainkan program-program lain dan dilakukan secara berkesinambungan. Konsep kesinambungan harus diperhatikan dalam bekerjasama agar hasil yang diperoleh dapat ditindaklanjuti dalam kegiatan-kegiatan selanjutnya. Terlebih lagi keberlanjutan dalam kolabarorasi untuk memelihara hasil pembangunan, oleh karena itu dalam kolaborasi peningkatan PAD diperlukan kemitraan mutualistik yaitu persekutuan dua pihak atau lebih yang sama-sama menyadari aspek pentingnya melakukan kemitraan, yaitu untuk saling memberikan manfaat dan mendapatkan manfaat lebih, sehingga akan dapat mencapai tujuan secara lebih optimal.

Model triple helix yang berkolaborasi secara muatualisme tersebut diharapkan dapat meningkatkan PAD Kota Baubau, bahkan lebih dari itu bahwa secara teoritis model triple helix menjadi solusi pemerintah dalam meningkatkn PAD serta menjadi pendukung pemerintah untuk merumuskan kebijakan-kebijakan yang berpihak pada kepentingan publik.

\section{Kesimpulan}

Pemerintah Kota Baubau dalam meningkatkan Pendapatan Asli Daerah (PAD) kurang menerapkan model triple helix. Upaya peningkatan PAD lebih pada kerjasama dan minim inovasi. Peran pemerintah sangat dominan dalam membuat regulasi, pengendali usaha dan pengarah. Selanjutnya akademisi sebatas melakukan penelitan dan pengabdian masyarakat sedangkan peran sektor bisnis sangat kurang, sektor bisnis berperan sebatas membayar pajak dan retribusi untuk meningkatkan PAD Kota Baubau. Model triple helix dalam peningkatan PAD Kota Baubau bersinergis dalam wilayah kewenangan masing-masing namum pemerintah sangat dominan. Oleh karena itu, agar PAD Kota Baubau dapat semakin meningkat, pemerintah sebaiknya menyeimbangkan perannya antara melaksanakan dan mengarahkan. Pemerintah juga harusnya lebih meningkatkan tekanan atau dorongan pada pihak ketiga untuk berkontribusi terhadap peningkatan PAD Kota Baubau. Model triple helix seharusnya berdasarkan kewenangan masing-masing helix dan berkolaborasi secara berkesinambungan. Sehingga diharapkan menjadi pertimbangan dan reverensi bagi peneliti selanjutnya dalam rangka optimalisasi peran Triple helix dalam penyelenggaraan pemerintahan di daerah dalam meningkatkan PAD Kota Baubau.

\section{Daftar Pustaka}

Afzal, M. N. I., Dutta, S., Mansur, K. B. H. M., \& Lawrey, R. (2017). Practice of Triple Helix (TH) Model in Malaysian Research Universities (RU). The Asian $\begin{array}{llll}\text { Journal of Technology Management } & \text { (AJTM), }\end{array}$ https://garuda.ristekbrin.go.id/documents/detail/603991 
Daulay, Z. A. A. (2018). Strategi Pengembangan Ekonomi Kreatif Dengan Metode Triple Helix (Studi Pada UMKM Kreatif di Kota Medan). Tansiq, 1(2), 169-190.

Etzkowitz, H. (2008). The Triple Helix: University-Industry-Government Innovation in Action. (I). Routledge.

Etzkowitz, Henry, \& Leydesdorff, L. (2000). The dynamics of innovation : from National Systems and " Mode 2 "' to a Triple Helix of university - industry government relations.". Research Policy, 29, 109.

Fadli, Yusuf, \& Nurlukman, A. D. (2018). Kolaborasi Pemerintah dalam Pengembangan Terpadu Wilayah Pesisir di Kabupaten Tangerang melalui Gerakan Pembangunan Masyarakat Pantai ( Gerbang Mapan ). Prosiding Seminar Nasional Unimus, 517-529.

Iskandar, D. (2013). KORELASI MODEL INOVASI TRIPLE HELIX DENGAN KINERJA. Telkom University.

Izzati, M. F., \& Wilopo. (2018). Implementasi Triple Helix Dalam Mendorong Pertumbuhan Daya Saing Untuk Menghadapi Masyarakat Ekonomi ASEAN. Jurnal Administrasi Bisnis, 55(1), 59-68.

Moleong, L. J. (2002). Metode Penelitian Kualitatif (enam belas). Rosdakarya.

Rufaidah, P. (2015). Branding Strategy Berbasis Ekonomi Kreatif: Triple Helix vs . Quadruple Helix (Issue July). https://doi.org/10.13140/RG.2.1.4132.7208

Sugiyono. (2017). Metode Penelitian Kebijakan Pendekatan Kuantitatif, Kualitatif, kombinasi, R\&D dan Penelitian Evaluasi. Alfabeta.

Wasitowati, A. (2015). Hubungan Triple Helix, Inovasi , Keunggulan Bersaing dan Kinerja. CBAM UNISSULA, 2(1), 320-324. 